\title{
Threats to the Proboscis Monkeys
}

\section{Sonia Jeffrey}

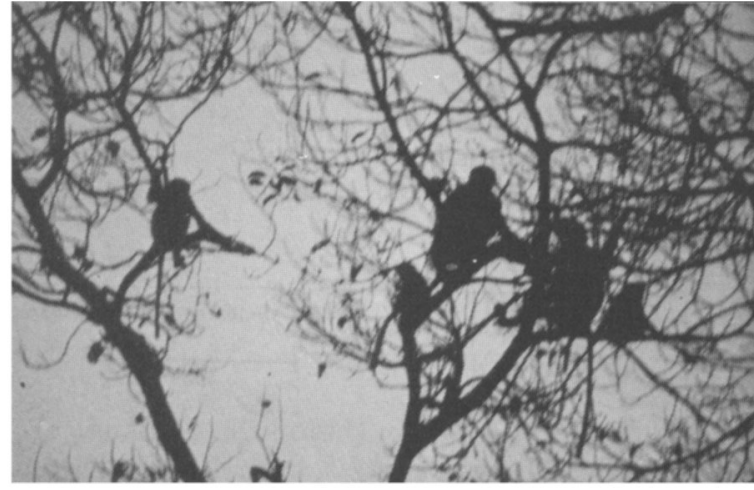

The endemic proboscis monkeys in Borneo live along the rivers and coasts where people also tend to concentrate. Hitherto there has been room for both. But in Kalimantan, logging and wood-processing industries are expanding rapidly Indonesia hopes to be self-sufficient in pulp and paper by 1984 - and this, together with the planned removal by the same date of $2 \frac{1}{2}$ million people from overcrowded Java, mostly to Kalimantan, could seriously affect the proboscis.

Proboscis monkeys Nasalis larvatus are endemic to the island of Borneo, where they are found along coastlines and rivers up to about $100 \mathrm{~km}$ from the sea. Van der Zon reported them $200 \mathrm{~km}$ inland on the Mentawai river but found this to be exceptional. ${ }^{4}$ None have ever been reported from the strip of Sarawak coast between the Rejang river in the east and Brunei. ${ }^{3}$ Elsewhere, especially in the more densely populated north Borneo, they have been eliminated from large areas of river and coast by hunting and farming. The species is given vulnerable status in the IUCN Red Data Book.

Proboscis have been recorded in areas of both wet and dry vegetation, but always on acidic soils and near rivers. Habitats vary from peat swamp forest, as in the Tanjung Puting nature reserve, and dry kerangus forest, as in the Samunsum wildlife sanctuary, to high forest of mixed dipterocarps growing on limestone, as in the Pengadan study area. Rivers are usually tidal and may be brackish or fresh, the former bordered by salt-water palms Nipa fructicans and pedada trees Sonneratia spp., the latter, further inland, by Pandanus spp., Ficus microcarpa and Octomeles sumatrana. Riverside vegetation is important because proboscis sleep in branches close to or overhanging rivers at night. Favourite trees include pedadas $F$. microcarpa and $O$. sumatrana because they also eat their leaves, and dipterocarps, e.g. Dryobalanops oocarpa. They may sleep on overhanging nipa palm fronds if the stands are extensive and there is nothing taller, although Kern reports that in Brunei Bay they showed no tendency to sleep on Nipa. ${ }^{2}$ Where swamp forest trees such as Ganua motleyana and Heritiera spp. occur by the river proboscis choose these because they are the tallest available. Where there are few if any trees, such as on farms or recently abandoned farms, there are no proboscis, and they have not been observed sleeping inland of rivers, although on one occasion following continual harassment at dusk they stayed hidden in trees a few metres back from the river until well after nightfall. They were rarely found in estuarine vegetation dominated by the mangrove Rhizophora apiculata, and never in pure stands of this species, although Kern reports that they eat its leaves. ${ }^{2}$ They preferred the greater species diversity in vegetation found further up the rivers. At dusk when they settled in their sleeping trees, they could be counted fairly accurately from the river, and where the habitat was suitable there were at least 20.2 animals per sq $\mathrm{km}$. 


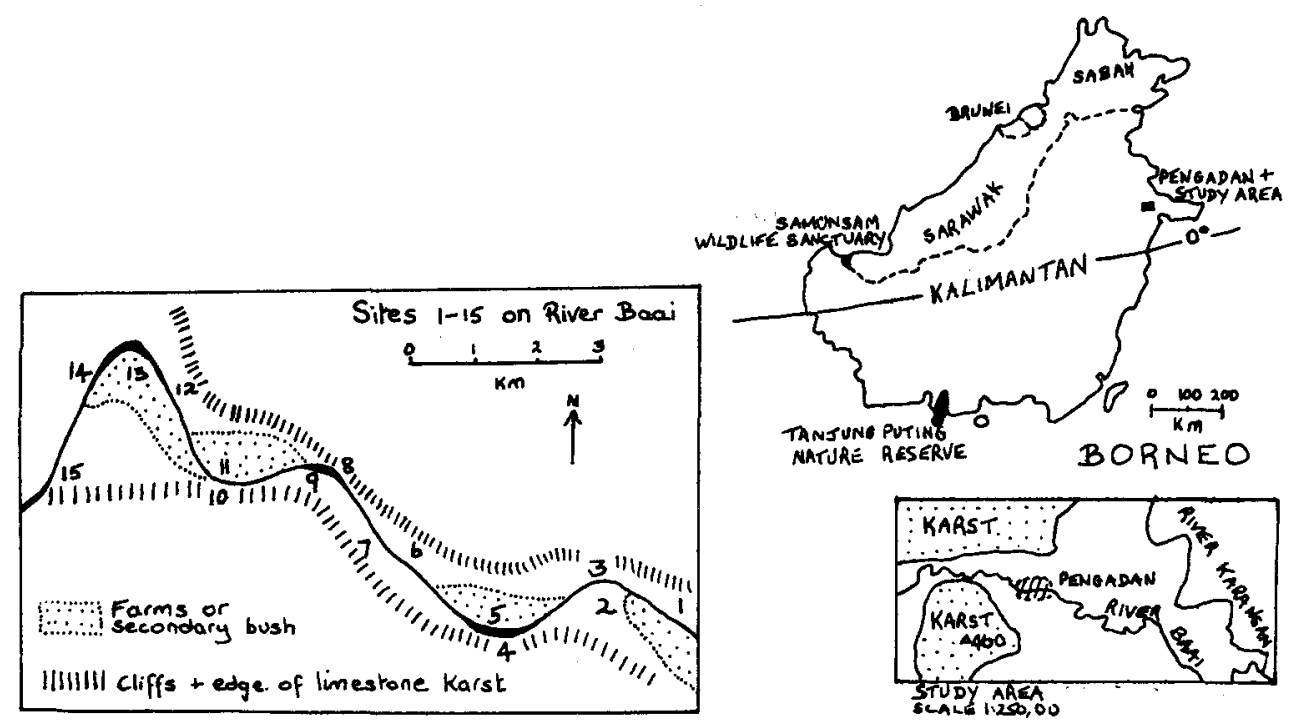

Proboscis were not often seen more than $3 \mathrm{~km}$ upstream of Pengadan, which approximately coincides with the end of the limestone. Occasionally they were seen in the seasonal swamp forest on smaller rivers $(5-10 \mathrm{~m}$ across) about $15 \mathrm{~km}$ upstream of Pengadan. Sleeping groups varied from one or two animals, always adult males, to nearly 100 in several trees on both sides of the river, but groups of 10 to 18 were by far the most usual. Larger groups than this comprised more than one foraging unit, the units arriving at different times and from different directions; large groups split up again the following morning.

The highest proboscis densities were in the limestone area upstream of Pengadan, where they were twice as numerous as downstream. Pengadan itself covers about $4 \mathrm{sq} \mathrm{km}$, extending for about $2 \mathrm{~km}$ along both banks of the river at the end of the limestone karst, and is considered to be a fairly effective barrier to proboscis migration up and downstream. Numbers along the river Baai downstream were comparable to those of the large and medium rivers at Tanjung Puting - about 10 per sq $\mathrm{km}$. Habitats here were generally low-lying, flat and seasonally swampy with some brackish water. Along the small river at Tanjung Puting, where abandoned farms and settlements had become large treeless grass areas, numbers were smaller. Forest on well drained soils immediately inland of the river Samunsam is classified as kerangas or heath forest. ${ }^{1}$

Since Kalimantan accounts for more than two-thirds of the island of Borneo, Indonesia has a major part in the protection of proboscis monkeys. They have been reported from four of Kalimantan's seven established nature reserves, including a sighting in Bukit Raya some $200 \mathrm{~km}$ from the coast (UNDP/FAO 1977), but their status and distribution there is not known. Very little has been written on their habitat requirements and whether existing reserves provide adequate protection. Proboscis occur in a wider variety of riverine habitats than was originally thought but no detailed ecological study has been made; previous studies were made in mangrove and swamp forest, none in tropical forest.

Population pressure is not a yet a serious problem in Kalimantan, with some six million people in about $50,000 \mathrm{sq} \mathrm{km}$. People tend to live on the coast and along rivers, especially those navigable by small craft. The Dayak settlers practised shifting cultivation with small plots scattered along the rivers, their only other disturbance of the riverine forest being the collection of rattan and housepoles. Deer and pig meat were preferred to monkey meat and were shot, using 


\section{Locality}

River Baai downstream of Pengadan

River Baai upstream of Pengadan

Tanjung Puting - large river

Tanjung Puting - medium river

Tanjung Puting - small river

River Samunsam

$\begin{array}{ccc}\text { Total } & \text { No. } & \\ \text { distance } & \text { counts } & \text { Maximum no. } \\ (\mathrm{km}) & \text { made }\end{array}$ individuals $/ \mathrm{sq} \mathrm{km}$

$\begin{array}{rrr}62 & 10 & 9.3 \\ 28 & 10 & 20.2 \\ 20 & 2 & 10.5 \\ 5 & 1 & 10.6 \\ 17 & 2 & 5.1 \\ \text { (estimated by K. Proud) } & 13.3\end{array}$

blow-pipes and poison darts or snared. In the last 12 years much larger settlements have spread up the rivers due to the rapid increase in logging companies, most of which have their base camp on the river and raft logs down it to the coast. Recent regulations (1980) stipulate that 60 per cent of logs produced must be processed locally, with the result that numerous sawmills and plymills have been established in remote areas, with many people coming in from other more remote Indonesian islands. Indonesia hopes to become self-sufficient in pulp and paper by 1984 , and there are major plans for the industry. The three major projects on Kalimantan rivers, two of which are just north of Pengadan, will use raw materials harvested from hardwood forests including swamp species such as Dacrydium spp. The Kayan river pulp and paper mill, with a proposed annual capacity of 135,000 tons from 600,000 ha of forest, is one of the smaller projects, but will lead to large-scale destruction of habitat.

Besides the spontaneous migration to work in Kalimantan's growing woodprocessing industries, Indonesia, aided by the World Bank, is moving 2.5 million people from crowded Java mostly to Kalimantan by 1984 . These people will be expected to farm the poor Kalimantan soils, which, when the forest cover is removed, quickly become leached of their nutrients. As food supplies become scarcer, hunting as an alternative source of protein and income will increase.

Apart from man, predation pressure on proboscis seems slight. Only one eagle, the black eagle Ictinaëtus malayensis, is large enough to eat adult primates, although the clouded leopard has been known to eat male proboscis. Crocodiles and pythons undoubtedly take the occasional small monkey.

It is unfortunate that the proboscis monkey's specialized habitat coincides with the very areas in Borneo that are to be colonized, farmed and industrialized by man. The need for more intensive studies of proboscis seems urgent, in the light of the increasingly gloomy reports on the chances of its survival.

\section{Acknowledgments}

I am indebted to the Fauna and Flora Preservation Society's Oryx 100\% Fund for assisting this research, and to Diana Mossman for help with my work in Tanjung Puting.

\section{References}

1. ASHTON, P.S. 1971. The plants and vegetation of Bako National Park. Malay. Nat. J. 24, 151-62.

2. KERN, J.A. 1964. Observations on the habits of the proboscis monkey Nasalis larvatus made in Brunei Bay area, Borneo. Zoologica 49, 3, 183-92.

3. PROUD, K. 1979. Pers. comm.

4. VAN DER ZON, A.P.M. 1976. Report on a field survey to east and central Kalimantan. FAO project INS/73/013.

Sonia Jeffrey, Pear Tree House, Hutton Magna, Richmond, N. Yorkshire. 